Discussion Paper No. 08-045

The Adoption of New Technologies and the Age Structure of the Workforce

Jenny Meyer

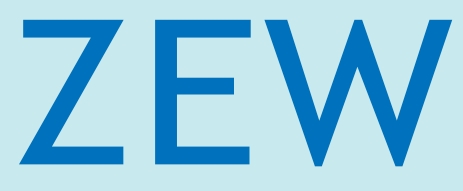

Zentrum für Europäische Wirtschaftsforschung $\mathrm{GmbH}$

Centre for European

Economic Research 
Discussion Paper No. 08-045

\title{
The Adoption of New Technologies and the Age Structure of the Workforce
}

\author{
Jenny Meyer
}

Download this ZEW Discussion Paper from our ftp server:

ftp://ftp.zew.de/pub/zew-docs/dp/dp08045.pdf

Die Discussion Papers dienen einer möglichst schnellen Verbreitung von neueren Forschungsarbeiten des ZEW. Die Beiträge liegen in alleiniger Verantwortung der Autoren und stellen nicht notwendigerweise die Meinung des ZEW dar.

Discussion Papers are intended to make results of ZEW research promptly available to other economists in order to encourage discussion and suggestions for revisions. The authors are solely responsible for the contents which do not necessarily represent the opinion of the ZEW. 


\section{Non-technical Summary}

Given the demographic development, which is characterized by an increasing life expectancy and a simultaneous decrease in birthrates, the age structure of the working population has been changing. The employment rate of individuals between 55 and 64 years has increased, particularly during the last five years, whereas the employment rate of individuals between 15 and 24 years has decreased in the same time period.

In an economy where knowledge is one of the important production factors and information processing is based on information and communication technologies (ICT), an efficient relationship between human capital and ICT usage is crucial for the successful performance and competitiveness of firms. As several studies show that older workers are less likely and less qualified to use ICT compared to younger employees, the question whether firms of the ICT-intensive service sectors with a high share of older workers are less likely to adopt new technologies arises. The results of this paper show that firms with a higher share of younger employees are more likely to adopt new technologies, and that the older the workforce is, the less likely is the adoption of new technologies.

Furthermore, there seem to be complementarities between the human capital of younger and older workers. Younger workers are more comfortable with the use of ICT and may learn more quickly. Older employees are more experienced and have a better knowledge of the intra-firm structure and the operating process. Thus, a heterogenous rather than a homogenous age structure of the workforce may be a supportive factor for the adoption of new technologies. The results of this paper however reveal that the distribution of the age of the workforce has no significant impact on the probability of adopting new technologies.

Previous studies find a complementary relationship between the use of ICT and modern human resource practices. Furthermore, the use of innovative workplace practices may provide a better environment for the adoption of new technologies. On the other hand, there is some empirical evidence that innovative workplace practices are negatively related to the employment of older workers. Since innovative workplace practices seem to have adverse relationships with ICT and new technologies on the on the one hand and the employment of older workers on the other hand this paper closes a research gap by analyzing the joint impact of the age of the workforce and the enhancement of teamwork as a tool of workplace organization on the probability of adopting new or significantly improved technologies. The results show that firms which have enhanced their teamwork and have a higher share of employees being younger than 30 years are less likely to adopt new or significantly improved technologies whereas firms that enhanced their teamwork and have a higher share of workers aged between 40 and 55 years are more likely to adopt new technologies. 


\section{Zusammenfassung}

Aufgrund der durch einen Anstieg der Lebenserwartung und einen gleichzeitigen Rückgang der Geburtenrate gekennzeichneten demografischen Entwicklung hat sich die Altersstruktur der arbeitenden Bevölkerung verändert. So ist die Beschäftigungsquote der 55-64-jährigen insbesondere in den vergangenen fünf Jahren angestiegen, während gleichzeitig ein Rückgang der Beschäftigungsquote der 15-24-jährigen erfolgt ist.

In einer Volkswirtschaft, in der Wissen ein wichtiger Produktionsfaktor ist und Informationsund Kommunikationstechnologien (IKT) zur Verarbeitung von Informationen benötigt werden, ist eine effiziente Verzahnung von Humankapital und IKT für den Erfolg und die Wettbewerbsfähigkeit von Unternehmen entscheidend. Mehrere Studien belegen, dass die Wahrscheinlichkeit der Anwendung von IKT bei älteren Arbeitnehmern geringer ausgeprägt ist als bei jüngeren Arbeitnehmern, und erstere hierfür auch weniger qualifiziert sind. Daher stellt sich die Frage, ob Unternehmen aus IKT-intensiven Dienstleistungssektoren, die einen hohen Anteil an älteren Beschäftigten haben, eine geringere Wahrscheinlichkeit des Einsatzes neuer Technologien aufweisen. Die Ergebnisse der vorliegenden Arbeit zeigen, dass Unternehmen, die einen höheren Anteil an jüngeren Beschäftigten haben, eine höhere Wahrscheinlichkeit aufweisen, neue Technologien einzusetzen. Je älter die Belegschaft eines Unternehmens ist, desto geringer ist dessen Wahrscheinlichkeit neue Technologien einzusetzen.

Des Weiteren scheinen Komplementaritäten zwischen dem Humankapital von jüngeren Beschäftigten und dem von älteren Beschäftigten zu existieren. Jüngeren Beschäftigten fällt der Umgang mit IKT leichter und sie lernen tendenziell schneller. Ältere Beschäftigte sind erfahrener und besitzen ein größeres Wissen über firmeninterne Strukturen und den Betriebsablauf. Daher ist eine heterogene Alterstruktur für die Wahrscheinlichkeit des Einsatzes neuer Technologien möglicherweise vorteilhafter als eine homogene Alterstruktur. Die Ergebnisse der vorliegenden Arbeit zeigen jedoch, dass die Altersverteilung keine Auswirkungen auf die Wahrscheinlichkeit des Einsatzes neuer Technologien hat.

Laut vorherigen Studien besteht ein komplementärer Zusammenhang zwischen der Nutzung von IKT und der Anwendung moderner Methoden der Personal- und Arbeitsorganisation. Des Weiteren kann durch die Anwendung innovativer Methoden der Arbeitsorganisation möglicherweise ein günstigeres Umfeld für den Einsatz neuer Technologien geschaffen werden. Auf der anderen Seite gibt es empirische Evidenz dafür, dass die Anwendung innovativer Methoden der Arbeitsorganisation mit der Beschäftigung älterer Arbeitnehmer negativ korreliert ist. Da die Anwendung innovativer Methoden der Arbeitsorganisation eine gegensätzliche Beziehung mit der Anwendung von IKT und neuen Technologien einerseits und mit der Beschäftigung älterer Arbeitnehmer andererseits zu haben scheint, wird mit dieser Arbeit eine Forschungslücke geschlossen, da die gemeinsame Auswirkung von Alterstruktur der Belegschaft und Verstärkung der Gruppenarbeit als Methode der Arbeitsorganisation auf die Wahrscheinlichkeit des Einsatzes neuer oder wesentlich verbesserter Technologien untersucht wird. Die Ergebnisse zeigen, dass 
Unternehmen, die Gruppenarbeit verstärkt haben und einen höheren Anteil an unter 30-jährigen beschäftigen, eine geringere Wahrscheinlichkeit aufweisen, neue bzw. wesentlich verbesserte Technologien einzuführen; wohingegen Unternehmen, die Gruppenarbeit verstärkt haben und einen größeren Anteil an 40-55-jährigen beschäftigen, eine höhere Wahrscheinlichkeit des Einsatzes neuer Technologien aufweisen. 


\title{
The Adoption of New Technologies and the Age Structure of the Workforce ${ }^{*}$
}

\author{
Jenny Meyer
}

March 2008用

\begin{abstract}
This paper provides firm-level evidence for the relationship between the age structure of the workforce and the adoption of new or significantly improved technologies in service sector firms. Furthermore, it closes a research gap by analyzing the joint impact of the age of the workforce and the enhancement of teamwork on the probability of adopting new technologies. The empirical analyses, that are based on a data set of 356 German firms from the knowledge-intensive services and ICT services sector, reveal three findings: Firstly, firms with a higher share of younger employees are more likely to adopt new technologies and the older the workforce is, the less likely is the adoption of new technologies. Secondly, the distribution of the age of the workforce has no significant impact on the probability of adopting new technologies. And thirdly, firms which enhanced their teamwork and have a higher share of younger workers are less likely to adopt new technologies whereas firms that enhanced their teamwork and have a higher share of older employees are more likely to adopt new technologies.
\end{abstract}

Keywords: age structure of the workforce, adoption of new technologies, ICT intensive services JEL-Classification: J14, O31

\footnotetext{
*I would like to thank Irene Bertschek, Daniel Cerquera, Ulrich Kaiser and Keld Laursen for helpful comments.

${ }^{\dagger}$ Correspondence: Jenny Meyer, Centre for European Economic Research (ZEW), ICT Research Group, P.O. Box 1034 43, D-68034 Mannheim, Germany, E-mail: meyer@zew.de

${ }^{\ddagger}$ This paper is a substantially revised version of the paper "Older Workers and the Adoption of New Technologies", ZEW Discussion Paper No. 07-050.
} 


\section{Introduction}

Given the demographic development, which is characterized by an increasing life expectancy and a simultaneous decrease in birthrates, the age structure of the working population has been changing. The employment rate of individuals between 55 and 64 years has increased, particularly during the last five years. In the EU-25 the employment rate of this age group has increased by 5.9 percent from 2000 to 2005 and amounted to about 42 percent in 2005 . The employment rate of individuals between 15 and 24 years has decreased by about 1.3 percentage points in the same time period (Eurostat 2007). This development has two implications. Firstly, the working population is getting older and secondly, the composition of the workforce in terms of age is changing.

In an economy where knowledge is one of the important production factors and information processing is based on information and communication technologies (ICT), an efficient relationship between human capital and ICT usage is crucial for the successful performance and competitiveness of firms. This is particularly true in the case of knowledge-intensive service providers (e.g. tax consultancy and accounting, architecture) and for information and communication technology service providers (e.g. telecommunication services, software and IT services).11 The first reason for this is the intensive use of ICT in these sectors, which rely on a continuous adoption of new technologies and software. The second reason is that for these firms the structure, quality and in-house organization of human capital are exceptionally important aspects in the production of the services they provide.

The rapid technological progress and the fast decline in knowledge on the one hand and the demographic development on the other hand provide a great challenge for the firms. Several studies show that older workers are less likely and less qualified to use ICT compared to younger employees (e.g. de Koning and Gelderblom 2006, Schleife 2006). Since firms of the ICT and knowledge-intensive service sector depend on ICT and the permanent adoption of its improvements, and since older workers have an issue with ICT use, the question whether firms of the mentioned sectors with a high share of older workers are less likely to adopt new technologies arises. This paper tries to answer this question by analyzing the relationship between the age of the workforce and the probability of adopting new technologies. The empirical analyses are based on a data set of 356 German firms from the knowledge-intensive services sector and the ICT services sector. Thus, they provide firm-level evidence on that issue for part of the service sector. The results show that firms with a higher share of younger employees are more likely to adopt new technologies, and that the older the workforce is, the less likely is the adoption of new technologies.

Furthermore, there seem to be complementarities between the human capital of younger and older workers (Lazear 1998). Younger workers are more comfortable with the use of ICT and may learn more quickly. As from a gerontological point of view, the fluid part of the brainpower-the part which is responsible for efficiently processing information and for adapting to new situations

\footnotetext{
${ }^{1}$ These sectors contribute to about eight percent of the German sales (Statistisches Bundesamt 2006).
} 
- decreases with age. By contrast, the cristalline intelligence, comprising verbal competence and experience, rather increases with age. Older employees are more experienced and have a better knowledge of the intra-firm structure and the operating process. Thus, a heterogenous rather than a homogenous age structure of the workforce may be a supportive factor for the adoption of new technologies. The results of this paper however reveal that the distribution of the age of the workforce has no significant impact on the probability of adopting new technologies.

Previous studies find a complementary relationship between the use of ICT and modern human resource practices, such as team work, flat hierarchies and performance-related wages (Bresnahan, Brynjolfsson, and Hitt 2002, Bertschek and Kaiser 2004). Furthermore, the use of innovative workplace practices may provide a better environment for the adoption of new technologies (Gera and Gu 2004, Webster 2004). On the other hand, there is some empirical evidence that innovative workplace practices are negatively related to the employment of older workers (Beckmann 2001, Aubert, Caroli, and Roger 2006). This suggests that older employees and innovative workplace practices do not fit well together. Since innovative workplace practices seem to have adverse relationships with ICT and new technologies on the on the one hand and the employment of older workers on the other hand this paper closes a research gap by analyzing the joint impact of the age of the workforce and the enhancement of teamwork as a tool of workplace organization on the probability of adopting new or significantly improved technologies. The results show that firms which have enhanced their teamwork and have a higher share of employees being younger than 30 years are less likely to adopt new or significantly improved technologies whereas firms that enhanced their teamwork and have a higher share of workers aged between 40 and 55 years are more likely to adopt new technologies. Thus, it seems that firms with a certain age structure need appropriate workplace organization in order to keep up with the technological development and therefore to stay competitive.

This paper is organized as follows: The second section reviews the background discussion in the existing economic literature on the relation between older workers, ICT and technology adoption and workplace organization. This is followed by a description of the used data, the 46th wave of the quarterly business survey among "service providers of the information society" conducted by the Centre for European Economic Research (ZEW), and some descriptive statistics. In the fourth section the estimation strategy and the empirical results are presented. Section five concludes and gives an outlook on further demands on research.

\section{Background Discussion}

This paper focuses on the relationship between the age structure of the workforce and the adoption of new or significantly improved technologies or software in ICT and knowledge-intensive service providing firms. Furthermore, it takes enhancement of teamwork as a tool of innovative workplace organization into account. Therefore it is related to several strands of the literature.

First, there is the literature on older workers and ICT. Furthermore, as the adoption of new 
technologies in the IT-related services sectors can be seen as a process innovation $2^{2}$ the literature on older workers and process innovations is also relevant. There are several studies using individual data that show that older workers are less likely and less qualified to use ICT compared to younger employees. Friedberg (2003) analyzes the relationship between computer use at work and the age of the workers by using individual data on American workers in the year 1993. Her results reveal that workers who are younger than 60 years use a computer more often than workers who are older than 60 years. Using individual-level data from 1997 of German male workers Schleife (2006) finds that the probability of computer use among workers aged between 55 and 64 years is significantly lower than that of workers between 25 and 34 years. Borghans and ter Weel (2002) and de Koning and Gelderblom (2006) show in their analyses that the computer skills of younger employees are better than those of older workers. De Koning and Gelderblom (2006) additionally show that the probability of using complicated ICT applications at work is lower among workers above 50 years. Other papers analyze the reverse effect: How does the use of IT or the adoption of new technologies affect the share of older workers? Bertschek (2004) shows in her analysis with German firm level data that the higher the IT-intensity, the lower the share of employees being 50 years or older. There is only weak empirical evidence for the opposite. Beckmann (2001) finds that there is a positive relationship between a firm's investment in IT and its employment of older workers. He measures ICT usage by using a dummy variable for ICT investments. This dummy variable, however, does not reflect to what extent the employees are affected by the corresponding investment in ICT.

The literature on the so-called age-biased technological change using firm-level data finds that technological progress negatively impacts the share of older workers or older low-skilled workers (Behaghel and Greenan 2007). Aubert, Caroli, and Roger (2006) examine the impact of innovations on the wage-bill share of workers from different age groups in France. They find that the wage-bill share of older workers (aged 50 years and above) is lower in innovative firms, i.e. innovative firms tend to be biased against age. Beckmann (2005) finds that technological change has a negative impact on the share of older employees in West German firms. Schneider (2007) uses a linked employer-employee approach to analyze the impact of the age structure of the workforce on product innovations of German manufacturing firms. He finds signifcant effects of the age structure of the workforce on the technological innovativeness and an inverse u-shaped age innovation profile. There are only few empirical investigations that analyze the relation between process innovation and the age of the workforce in manufacturing firms. Rouvinen (2002) analyzes the characteristics of product and process innovations in the Finnish manufacturing sector. He finds that an increasing average age of the employees, although he uses this variable as proxy for firm age, reduces the probability of process innovation. Another analysis that examines the relation between innovation and the age of the workforce comes from Nishimura,

\footnotetext{
${ }^{2}$ According to the Oslo Manual (OECD, Eurostat 2005), "a process innovation is the implementation of a new or significantly improved production or delivery method". This includes significant changes in equipment, techniques and/or software (OECD, Eurostat 2005). The firms of these service industries do not invent or create new processes. As Hempell (2003) states, the service providing firms, especially those of the knowledge-intensive branches rely on the inputs of the industry. Thus, a process innovation is a change in the process of creating services, caused by the introduction of new technologies or software, provided by the industry or other service providers.
} 
Minetaki, Shirai, and Kurokawa (2004). They investigate the interaction between age and the qualification of the employees and its impact on technological progress in Japanese industries. Using only a small sample, they find no significant impact of older workers (above 40 years) with high qualification (share of old workers with high education to the total labor inputs) on the rate of technological progress in non-manufacturing industries. However, they find that the share of older workers with a high qualification reduced the rate of technological progess in the manufacturing industries in the 1990s.

The relationship between technological change and ICT on the one hand and older workers on the other hand is explained by two main hypotheses: (1) Using two data sets from the U.S., Friedberg (2003) states that the less frequent use of computers by older workers is related to their imminent retirement. Investing in their computer skills does not pay off any longer. Friedberg (2003) finds that computer users tend to retire later than non-users which is probably due to comparative advantages and because they are ready to invest in training. Furthermore, her results reveal that the less frequent use of computers by older workers can be explained by the differences according to occupations and education. Empricial evidence for Germany found by Schleife (2006) suggests that age does not play a significant role in the retirement decision when other factors such as qualification, work experience, etc. are considered. Borghans and ter Weel (2002) even find that the imminent retirement of older workers is no significant parameter affecting the non-use of computers. The discussion about technological change and the retirement decision is related to the vintage human capital models (MacDonald and Weisbach 2004). Within technological change and innovation human capital may become obsolete. Thus, older workers may resist to innovation when their human capital might be depreciated. (2) Weinberg (2004) argues from a different point of view. He states that the ability to learn how to use a computer declines with increasing age. This is in line with the so-called "deficit-model" that explains the process of aging from a gerontological point of view. This model assumes that older people loose important features, showing defects and deficits compared to younger ones. This affects physical (declining physical strength or decelerated reactions) and psychic skills (cutback of brainpower, especially of fluid brainpower which is needed amongst others for new solutions and a fast processing of information (Börsch-Supan, Düzgün, and Weiss 2006)) as well as limited interests and reduced social activities (Walter 1995). This can be related to the economic context and the labor market. Asked what kind of attributes emerge in which age group and how important those features are, personnel officers reply that in general older workers show a lower learning aptitude, a lower willingness to learn or flexibility compared to younger workers (Boockmann and Zwick 2004). These skills, however, are especially important for the implementation of process innovation in terms of adopting new technologies or software.

Another important aspect is the age distribution within the workforce. As Lazear (1998) already states, there are complementarities between the human capital of younger and older workers. Younger employees are more comfortable with the use of ICT and older employees have a better knowledge of the intra-firm structures and the operating process. Therefore, the complementarities between older and younger workers can be effective, especially in the case of adopting 
new technologies or software in the process of service creation. The motivation and the attitude towards using technology (Morris and Venkatesh 2000) of younger workers can lead to spill-over effects. On the one hand the younger employees can help the older ones by explaining them the innovations, while on the other hand sharing their enthusiasm with them.

Empirical evidence of the success of age-mixed teams can be found in the analysis of Grund and Westergard-Nielsen (2008). In a different context they find an inverse u-shaped relation between the average age of the employees and its standard deviation and firm productivity. This means it is better to have a heterogenous workforce than a homogenous one, as long as it is not too heterogenous. Pelled, Eisenhardt, and Xin (1999) find a positive interrelation between age heterogeneity and group performance by analyzing 45 teams of 3 firms although the group performance is only evaluated by the team manager. This result is supported by the work of Kilduff, Angelmar, and Mehra (2000) who use data of 159 managers playing a business game. The analysis of Simons, Pelled, and Smith (1999), however, reveals the opposite: They find a negative relationship between heterogeneity of age and the growth of sales analyzing data of 57 manufacturing firms.

There is a broad literature suggesting that the implementation of new IT systems often goes hand in hand with organizational changes in firms. Thus, IT investments and organizational investments are interpreted as strategic complementarities (Brynjolfsson and Hitt 2000, Bresnahan, Brynjolfsson, and Hitt 2002, Bertschek and Kaiser 2004). This discussion is mainly focussed on decentralizing organizational measures which imply a greater involvement of employees in decision-making processes and an enlargement of their responsibilities. Some examples are team work, flat hierarchies, autonomous working groups or incentive pay - measures supposed to positively affect the information flow within firms and the motivation of the employees. The use of innovative workplace practices such as teamwork and flat hierarchies (Gera and Gu 2004, Webster 2004) may provide a better environment for the adoption of new technologies because of the existing complementarities (Milgrom and Roberts 1990, Hitt and Brynjolfsson 1997, Bresnahan, Brynjolfsson, and Hitt 2002). The implementation of a new information and communication system or a new software system often requires a restructuring of the firm to use the new system efficiently. Thus, it is likely that the workplace organization has to be changed accordingly to make the operating process more efficient. On the other side, it is also possible that the introduction or enhancement of teamwork and the flattening of hierarchies may have an impact on the probability of introducing new technologies or software.

Taking into account the complementary relationship between ICT and workplace organization, there is also some empirical evidence on the relationship between older workers and organizational structures. These studies find that innovative workplace practices granting more decisionmaking authority and responsibility to employees are negatively related to the employment of older workers. Using West German firm level data for the years 1993 to 1995 Beckmann (2001, 2005) finds that organizational changes have significantly negative effects on the percentage share of workers aged 50 or more. Aubert, Caroli, and Roger (2006) provide empirical evidence for 
France using linked employer-employee data. They find that an increase in the use of innovative workplace practices in the firm comes along with a decline in the percentage share of older workers. However, it is not only the internal organization that may affect the probability to introduce new technologies or software, but also the external environment of the firm plays a role. The market and customers with their requirements (de Jong, Bruins, Dolfsma, and Meijaard 2003) and the competitive situation may result in the need to introduce new technologies or software to keep up with the surrounding development.

\section{Data and Descriptive Statistics}

The data used for the empirical analyses is taken from the quarterly business survey among the "service providers of the information society" conducted by the Centre for European Economic Research (ZEW) in cooperation with the credit rating agency Creditreform. The sector "service providers of the information society" comprises nine industries belonging to the information and communication technology service providers (e.g. software and IT services) and the knowledgeintensive service providers (e.g. tax consultancy and accounting) ${ }^{3}$ Every quarter a single-page questionnaire is sent to about 3,500 mostly small- or medium-sized firms. At each wave, the survey achieves a response rate of about $25 \%$. It is a random sample, stratified with respect to company size, region and sector affiliation. The questionnaire is divided into two parts. In the first part, firms assess their current business development with respect to the previous quarter as well as their expectations for the next quarter. The second part is dedicated to questions concerning current economic issues, ICT diffusion or particular information about the firms e.g. their innovative activities or training behavior. The questions of the second part change quarterly with selected questions being repeated annually. The survey is designed as a panel $4_{4}^{4}$ This paper uses the data of the 46th wave (3rd quarter 2005) $5^{5}$ Due to item non-response the number of observations is reduced and thus the final data set composes 356 firms with at least 2 and at most 250 employees.

Former waves of the data have previously been used to analyze the productivity effects of organizational change (Bertschek and Kaiser 2004) and the relationship between managerial ownership and firm performance (Mueller and Spitz-Oener 2006).

The adoption of new or significantly improved technologies and software is represented by a dummy variable ${ }^{6}$ The share of employees in four age groups (younger than 30 years, between

\footnotetext{
${ }^{3}$ For further details on the nine industries, their industrial classification and their distribution within the sample see the appendix and Table A.1 in the appendix.

${ }^{4}$ Although the question concerning the technology adoption has been asked for the fourth time, panel data estimations cannot be provided. The survey among "service providers of the information society" is a very versatile data set where firms take part on an irregular basis. The use of the panel data causes a great loss of observations and unobserved heterogeneity could not be taken into account because there is only a very tiny fraction of firms for which data are available for more than two periods in a row.

${ }^{5}$ The 46th wave of the survey includes information on the age structure of the workforce, the qualification level of the employees, the implemented process, product and organizational innovations, the export activity and the existence of foreign competitors.

${ }^{6}$ The firms answered the following question: Did you adopt new or significantly improved technologies in the last 12 months (e.g. new electronic data processing systems, Internet)?
} 
30 and 40 years, between 40 and 55 years and older than 55 years) are used to analyze how the age of the workforce affects the adoption of new technologies or software 7 In a second step, the shares of the employees in the four age groups are used to calculate a Herfindahl index, measuring the concentration of the employees age in the firm. Furthermore, interactions between the shares of employees in these age groups and a dummy variable for enhancement of teamwork are provided to test whether complementarities exist. 8

Table 3.1 shows some descriptive statistics of the data for the whole sample. It compares those firms that have adopted new or significantly improved technologies in the last twelve months to those firms that have not. It becomes clear that there are some differences. As expected, the share of younger employees is higher and the share of older employees is lower in firms that have adopted new technologies. In firms that have adopted new or significantly improved technologies, the share of employees younger than 30 years is about 25.1 percent on average, compared to 19.1 percent in firms that have not adopted new technologies. The share of employees being 55 years and older is about 12.5 percent in firms that have not adopted new or improved technologies compared to about 9.6 percent in the firms that have adopted technologies. Most of the employees belong to the so-called prime-age workers between 30 and 55 years, in the whole sample these are about 66.8 percent of the employees.

The distribution of the age of the workforce measured by the Herfindahl index does not differ significantly between the firms that have adopted new technologies and those that have not. The Herfindahl index lies between zero and one, and the higher it is the stronger is the concentration of age within the workforce. For firms that have adopted new technologies the Herfindahl index is about 0.41 . It is 0.42 for firms that have not adopted new technologies.

Table 3.1: Descriptive statistics

\begin{tabular}{l|c|c|c}
\hline \hline Feature & $\begin{array}{c}\text { Firms that adopted } \\
\text { new technologies }\end{array}$ & $\begin{array}{c}\text { Firms that did not } \\
\text { adopt new technologies }\end{array}$ & $\begin{array}{c}\text { Total } \\
\text { sample }\end{array}$ \\
\hline share of employees younger than 30 years & $25.1 \%$ & $19.1 \%$ & $22.2 \%$ \\
share of employees between 30 and 40 years & $32.8 \%$ & $32.4 \%$ & $32.6 \%$ \\
share of employees between 40 and 55 years & $32.5 \%$ & $36.0 \%$ & $34.2 \%$ \\
share of employees older than 55 years & $9.6 \%$ & $12.5 \%$ & $11.0 \%$ \\
Herfindahl index & 0.41 & 0.42 & 0.41 \\
\hline share of highly qualified employees & $38.7 \%$ & $36.9 \%$ & $37.8 \%$ \\
enhancement of teamwork & $48.2 \%$ & $31.2 \%$ & $36.8 \%$ \\
changed customer requirements & $79.3 \%$ & $55.2 \%$ & $67.6 \%$ \\
foreign competitors & $58.6 \%$ & $46.7 \%$ & $52.7 \%$ \\
exporters & $35.8 \%$ & $34.5 \%$ & $35.2 \%$ \\
firm size (number of employees) & 39.2 & 34.3 & 36.8 \\
firm age (in years) & 16.8 & 15.1 & 15.9 \\
\hline \hline
\end{tabular}

Source: ZEW, own calculations

When firms that have adopted new or significantly improved technologies are compared to those

\footnotetext{
${ }^{7}$ The share of employees being younger than 25 years and being between 25 and 30 years old have been combinded to the group younger than 30 years.

${ }^{8} \mathrm{~A}$ list of the variables used and some summary statistics can be found in Table A.2 in the appendix.
} 
that have not adopted new technologies it can be seen that there is almost no difference between them in terms of the share of highly qualified employees, in particular 38.7 percent compared to about 36.9 percent (see Table 3.1). This seems striking as there has been a lot of discussion in the literature on skill-biased technological change (e.g. Chennells and van Reenen 2002, Card and DiNardo 2002), suggesting that the use of new technologies and the diffusion of IT change the skill requirements (Autor, Levy, and Murnane 2003, Spitz-Oener 2006) and thus lead to an increase in demand for highly qualified labor (see for instance Falk (2002) for the case of Germany).

Table 3.1 reveals that the share of firms which have enhanced teamwork as a tool of workplace organization in the last three years is significantly higher among firms that have adopted new technologies than among firms that have not adopted new technologies. Among firms that have adopted new technologies about 48.2 percent have enhanced their teamwork, compared to about 31.2 percent of the firms that have not adopted new technologies. On the one hand, this can be a signal for the generally higher propensity to change and innovate in certain firms. On the other hand it reflects the complementary relationship between ICT and workplace organization.

More than half of the firms that have adopted new technologies compete with foreign firms, whereas this share is lower among the firms that have not adopted new or significantly improved technology as Table 3.1 shows. About 80 percent of the firms that have adopted new technologies say that customer or market requirements have changed during the last three years. On the other side, only more than half of the firms that have not adopted new technologies had to face changed customer requirements.

The exporting activities of the two types of firms differ only slightly. About 36 percent of the firms that have adopted new or improved technologies in the last twelve months export services and about 34 percent of the firms that have not adopted new technologies do so. Moreover, larger firms are more likely to adopt new technologies than smaller firms. Those firms that have adopted new technologies or software in the last twelve months have on average about 39 employees, whereas firms, that have not adopted new technologies have only about 34 employees on average. In general, the firms in the sample are rather young, about 16 years on average as can be seen in Table 3.1, whereas firms that have adopted new technologies are somewhat older than firms that have not adopted new technologies.

The descriptive analysis of the data also shows that the adoption of new or significantly improved technologies varies across industries. Firms belonging to the software and IT services branch are most likely to adopt new technologies. Slightly more than 60 percent of these firms introduced new technologies or software within the last twelve months. Firms belonging to the research and development sector, however, rarely adopt new technologies, about 36 percent of these firms report to have adopted new or significantly improved technologies (see Figure A.1 in the appendix). 


\section{Empirical Analysis}

\subsection{Estimation Strategy}

In the following, the hypothesis that firms with a higher share of older workers are less likely to adopt new or significantly improved technologies is analyzed 99 The variable measuring the decision to adopt new or significantly improved technologies and software is a dummy variable with the following form:

technology adoption $= \begin{cases}1 & \text { if the firm adopted new technologies } \\ 0 & \text { if the firm did not. }\end{cases}$

Thus, the decision to adopt new or significantly improved technologies is binary, but will only be made if the benefit of the technology adoption is positive. The benefit, however, cannot be observed and therefore one can revert to an underlying latent index model to model the binary choice. The latent variable, denoted technology adoption*, is a function of observed characteristics, say $X$, and of unobserved characteristics, say $\epsilon$ :

$$
\text { technology adoption }{ }^{*}=\beta^{\prime} X+\epsilon
$$

As technology adoption $=1$ can only be observed if technology adoption ${ }^{*}>0$, the probability of technology adoption is given by:

$$
\begin{aligned}
\operatorname{prob}(\text { technology adoption }=1) & =\operatorname{prob}\left(\text { technology adoption }{ }^{*}>0\right)= \\
\operatorname{prob}\left(\beta^{\prime} X+\epsilon>0\right) & =\operatorname{prob}\left(-\epsilon<\beta^{\prime} X\right)=F\left(\beta^{\prime} X\right)
\end{aligned}
$$

where $F$ denotes the distribution function of $-\epsilon$, respectively $\epsilon$. Since I assume the error term in the decision of adopting technology to be normally distributed, $F$ indicates the cumulative standard normal distribution $\Phi$. Thus, it is a Probit model of the following form:

$$
P(\text { technology adoption }=1)=\Phi\left(\beta^{\prime} X\right) .
$$

$X$ is a vector containing the following variables. Four variables indicate the age of the workforce: share of employees younger than 30 years (u30), share of employees between 30 and 40 years (b3040), share of employees between 40 and 55 years (b4055) and share of employees older than 55 years (o55) 10 The qualification of the employees seems to be related to the adoption of technology since neither the introduction nor the execution of innovations can be successfully done without the suitable know-how. A variable presenting the share of highly qualified employees (highqual) is considered. Variables for firm characteristics as firm size (log. number of employees, size) and firm age (in years, fage) are also included. Bigger firms may profit from emerging economies of scale. Older firms may be more traditional than their younger

\footnotetext{
${ }^{9}$ All calculations and estimations of this paper were done with STATA 10.0.

${ }^{10}$ Estimated altogether while the share of employees younger than 30 years presents the reference category. Estimated seperately while the respective share of employees not being in the particular age group presents the reference category.
} 
counterparts and therefore less inclined to change the operating process. A dummy variable for exporting activities (exp) and a dummy variable for foreign competition (comp) are regarded. Exporters may depend on the latest communication technologies in order to stay in contact with their customers abroad. The enhancement of teamwork in the last three years is presented by a dummy variable (team). Teamwork is supposed to positively affect the information flow within firms and thus supports technology adoption. A dummy variable for changes in the market or customer requirements in the last three years $(r e q)$ and a dummy variable for product innovation ( prod) are additionally considered. The introduction of a product innovation may lead to a change in the operating process and therefore to the adoption of new technologies. Nine dummy variables presenting the region (East/West Germany) and the sectors are also contained ${ }^{11}$ In a second step, the shares of employees are replaced by the Herfindahl index variable $(h i)$ that indicates the concentration of the employees age within the firm. An interaction term between each share of employees of a certain age group and the dummy variable enhancement of teamwork $\left(\right.$ team $^{*} u 30$, team $^{*} b 3040$, team $^{*} 64055$, team $^{*}$ o55) is part of $X{ }^{12}$

Four different specifications are taken into account to check the robustness of the results. Note however, that there might be some endogeneity problems. The age of the workforce may be endogenous due to selection. On the one hand, companies might dismiss older workers who are not productive and adaptive enough by early retirement programs, for instance. On the other hand the firms might hire younger workers who are more comfortable with the use of ICT and more flexible regarding new technological developments. Otherwise there might be self selection when older employees decide to leave the labor market if their workplaces are affected by technological change and if sufficient support by social security systems is available. Considering the development of the percentage shares of older, middle-aged and younger workers since 2002 reveals that the age of the workforce can be assumed to be a constant factor that does not significantly change within twelve months. Therefore, three other waves of the business survey among the "service providers of the information society" are used. As Table A.3 in the appendix shows, the average variation of the proportion of employees belonging to a certain age group over the time period from 2002 to 2005 is only small. It seems there is no systematic selection mechanism. This is supported by the results of the Kernel density estimations in Figure A.2 in the appendix as well as by a Kolmogorov-Smirnov test that indicate that the distributions of the proportion of younger, middle-aged and older workers do not differ significantly between two consecutive years.

Moreover, the dummy variable for product innovation may be endogenous, as there might be a structural reverse causality between the adoption of new technologies and the introduction of new or improved services. However, the data does not provide appropriate instruments to control for this potential endogeneity.

Since the estimated coefficients in a Probit model only allow to make a statement on the significance and the sign of an effect but not on its extent, the analysis focuses on the marginal effects:

\footnotetext{
${ }^{11}$ The sector marketing presents the reference category.

${ }^{12}$ Only when each share of employees is estimated seperately.
} 


$$
\frac{\delta \text { prob(technology adoption }=1)}{\delta u 30}=\Phi^{\prime}\left(\beta_{0}+\beta_{1} u 30+\beta_{2} b 3040+\ldots\right) \beta_{1} .
$$

The marginal effect of the interaction term, which is considered in the third part of the empirical analysis, is, by default, given by:

$$
\frac{\delta p r o b(\text { technology adoption }=1)}{\delta \text { team } * u 30}=\beta_{3} \Phi^{\prime}\left(\beta_{0}+\beta_{1} u 30+\beta_{2} \text { team }+\beta_{3} \text { team } * u 30+\ldots\right) .
$$

As pointed out by Ai and Norton (2003), the interaction effect is the cross derivative or (cross difference):

$$
\begin{array}{cll}
\frac{\Delta \text { prob(technology adoption }=1)}{\text { uu30 }} & =\Phi^{\prime \prime}\left(\beta_{0}+\beta_{1} u 30+\beta_{2} \text { team }+\beta_{3} \text { team } * u 30+\ldots\right) . \\
\left(\beta_{2}+\beta_{3} \text { team }\right)\left(\beta_{1}+\beta_{3} u 30\right) & +\Phi^{\prime}\left(\beta_{0}+\beta_{1} u 30+\beta_{2} \text { team }+\beta_{3} \text { team } * u 30+\ldots\right) \beta_{3} .
\end{array}
$$

Since we have a Probit model, there are some implications (see Ai and Norton (2003)) that cause the sign of the coefficient (here $\beta_{3}$ ) not necessarily to indicate the sign of the interaction effect. Therefore, the magnitude of the interaction effect, its standard error and z-statistic are calculated for each observation. According to Ai and Norton (2003) the standard errors are applied by using the Delta method.

\section{$4.2 \quad$ Results}

Table 4.1 reports the average marginal effects of the Probit estimations ${ }^{13}$ Compared to the share of employees younger than 30 years an increase in the share of employees older than 30 years is related to a decrease in the probability of adopting new or significantly improved technologies, whereas the older the workforce is, the less likely is the adoption of new technologies. Table 4.1 shows that the probability to adopt new technologies is related to a decrease of 0.34 percentage points if the share of employees between 30 and 40 years decreases by one percent compared to the share of employees younger than 30 years (specification (1), second column of Table 4.1). An increase in the share of employees between 40 and 55 years by one percent is related to a lowering of the probability of introducing new technologies by about 0.37 percentage points (specification (1)). An increase in the share of workers older than 55 years by one percent, compared to the share of workers younger than 30 years, is related to a decrease of 0.66 percentage points in the likelihood of the adoption of new technologies or software (specification (1)). These results are robust as they hold for all four specifications.

Estimating the respective impact of the four age groups on the probability of adopting new technologies it can be seen that firms with a higher share of employees younger than 30 years have a higher probability to adopt new technologies. On the other hand firms with a higher share of employees being between 40 and 55 years or older than 55 years are less likely to introduce new

\footnotetext{
${ }^{13}$ Only the marginal effects are discussed in the following. Table A.4 in the appendix shows the coefficients of the Probit estimations.
} 
or significantly improved technologies (see Tables A.5, A.7 and A.8 in the appendix). The share of employees between 30 and 40 years, however, has no significant impact on the probability of adopting new technologies (see Table A.6 in the appendix).

In particular, an increase in the share of employees younger than 30 years is related to an increase in the probability of adopting new technologies (see Table A.5 in the appendix). This result holds for all four specifications. This may be due to two reasons: Workers younger than 30 years have a high productivity and a high potential in terms of mastering equipment and software (Tijdens and Steijn 2005). Moreover, the knowledge of this age group may still be up to date as their educational achievement is recent.

Table 4.1: Marginal effects of Probit Estimations

\begin{tabular}{|c|c|c|c|c|}
\hline \multicolumn{5}{|c|}{ dependent variable: dummy for adoption of new technologies } \\
\hline & $(1)$ & $(2)$ & $(3)$ & $(4)$ \\
\hline share of employees younger than 30 years & & reference & category & \\
\hline share of employees between 30 and 40 years & $\begin{array}{c}-0.343^{* *} \\
(0.174)\end{array}$ & $\begin{array}{c}-0.366^{*} \\
(0.178)\end{array}$ & $\begin{array}{c}-0.353^{*} \\
(0.191)\end{array}$ & $\begin{array}{l}-0.356^{*} \\
(0.182)\end{array}$ \\
\hline share of employees between 40 and 55 years & $\begin{array}{c}-0.373^{* *} \\
(0.157)\end{array}$ & $\begin{array}{c}-0.483^{* *} \\
(0.160)\end{array}$ & $\begin{array}{c}-0.451^{* *} \\
(0.170)\end{array}$ & $\begin{array}{c}-0.485^{* * *} \\
(0.182)\end{array}$ \\
\hline share of employees older than 55 years & $\begin{array}{c}-0.659^{* * *} \\
(0.228)\end{array}$ & $\begin{array}{c}-0.793^{* * *} \\
(0.232)\end{array}$ & $\begin{array}{c}-0.801^{* * *} \\
(0.245)\end{array}$ & $\begin{array}{c}-0.732^{* * *} \\
(0.241)\end{array}$ \\
\hline firm size (log. number of employees) & $\begin{array}{c}0.017 \\
(0.024)\end{array}$ & $\begin{array}{l}-0.005 \\
(0.026)\end{array}$ & $\begin{array}{l}-0.024 \\
(0.027)\end{array}$ & $\begin{array}{l}-0.027 \\
(0.026)\end{array}$ \\
\hline share of highly qualified employees & $\begin{array}{c}0.064 \\
(0.103)\end{array}$ & $\begin{array}{c}0.042 \\
(0.114)\end{array}$ & $\begin{array}{c}0.033 \\
(0.115)\end{array}$ & $\begin{array}{c}0.040 \\
(0.114)\end{array}$ \\
\hline firm age & & $\begin{array}{l}0.005^{*} \\
(0.003)\end{array}$ & $\begin{array}{l}0.005^{*} \\
(0.003)\end{array}$ & $\begin{array}{l}0.006^{* *} \\
(0.003)\end{array}$ \\
\hline exporter yes/no & & $\begin{array}{l}-0.008 \\
(0.064)\end{array}$ & $\begin{array}{l}-0.041 \\
(0.064)\end{array}$ & $\begin{array}{l}-0.042 \\
(0.061)\end{array}$ \\
\hline foreign competitors yes/no & & $\begin{array}{c}0.070 \\
(0.059)\end{array}$ & $\begin{array}{c}0.044 \\
(0.061)\end{array}$ & $\begin{array}{c}0.021 \\
(0.060)\end{array}$ \\
\hline change of customer requirements yes/no & & & $\begin{array}{c}0.242^{* * *} \\
(0.064)\end{array}$ & $\begin{array}{c}0.202^{* * *} \\
(0.064)\end{array}$ \\
\hline enhancement of teamwork yes/no & & & $\begin{array}{l}0.123^{* *} \\
(0.059)\end{array}$ & $\begin{array}{c}0.066 \\
(0.057)\end{array}$ \\
\hline product innovation yes/no & & & & $\begin{array}{c}0.315^{* * *} \\
(0.060)\end{array}$ \\
\hline number of observations & 356 & 320 & 284 & 259 \\
\hline McFadden $R^{2}$ & 0.05 & 0.07 & 0.14 & 0.24 \\
\hline
\end{tabular}

Significance levels : $\quad *: 10 \% \quad * *: 5 \% \quad * * *: 1 \% \quad$, heteroscedasticity-robust standard errors

Dummies for sectors and East Germany are included.

An increase in the share of employees between 40 and 55 years (see Table A.7 in the appendix) or in the share of employees older than 55 years (see Table A.8 in the appendix) is related to a decrease in the likelihood of adopting new technologies. Hence, an older staff is negatively related to the likelihood of introducing new or significantly improved technologies in the operating 
process. This is partly in line with the finding of Schneider (2007) who finds an inverse u-shaped age innovation profile in the manufacturing sector. Furthermore, the results support the empirical evidence found by Rouvinen (2002) and Nishimura, Minetaki, Shirai, and Kurokawa (2004). They also find a negative influence of older employees on the (process) innovation probability in the manufacturing industries. This issue may be explained by two different hypotheses. Firstly, it may be that older workers have more problems to adopt to changes in the operating process, especially when they have had a longer tenure. This is supported by the "deficit-model" mentioned before and by the study of Morris and Venkatesh (2000). This effect could be boosted by the kind of changes, especially caused by the challenges of new technologies and software that cause problems for older workers as stated by e.g. de Koning and Gelderblom (2006) and Schleife (2006) or Borghans and ter Weel (2002), who find that employees being older than 30 years have lower ICT-skills. Secondly, older firms which mainly employ older workers with longer job tenure may be more traditional and therefore less inclined to innovate or to change the working routine at all. This explanation, however, can be excluded, since the consideration of firm age in the estimation does not change the results (see Tables 4.1 and A.5- A.8 in the appendix).

Table 4.2 shows the marginal effects of the Probit estimations of the age distribution of the workforce measured by the Herfindahl index 14 The coefficient as well as the marginal effect of the Herfindahl index, however, is not statistically significant except for the fourth specification, where it is only significant at the ten percent level. Although the age of the workforce seems to matter, its structure, means the distribution of the age of the workforce, however, has no significant impact on the probability of adopting new technologies. Regarding the descriptive statistics which suggested that there is no difference in the distribution of the age of the workforce, this result is not that surprising.

Each last column of Tables A.5 - A.8 in the appendix shows the estimated coefficient of the interaction effect between the proportion of employees of a particular age group and the dummy variable enhancement of teamwork. Table 4.3 shows the correct marginal effect of the interaction effects (see equation 6). Only the interaction term between the proportion of employees younger than 30 years and the proportion of employees between 40 and 55 years is statistically significant. The interaction term between enhancement of teamwork and employees younger than 30 years is negatively related to the probability of adopting new technologies. Younger workers, especially when they have a short tenure may be more uncomfortable in a team, where hierarchies are often flatter, and prefer working alone with clear instructions from a higher hierarchy level. As younger employees seem to be more comfortable with the use of ICT and more adaptive concerning new technologies they might need less help or support from a team. The interaction between enhancement of teamwork and the proportion of employees between 40 and 55 years is positively related to the probability of adopting new technologies. Due to the mentioned complementarities between the human capital of older and younger workers, employees aged between 40 and 55 years may benefit from the ICT knowledge of the younger workers

\footnotetext{
${ }^{14}$ The coeffiencts of the estimation results are shown in Table A.9 in the appendix.
} 
Table 4.2: Marginal effects of Probit Estimations: age concentration

\begin{tabular}{|c|c|c|c|c|}
\hline \multicolumn{5}{|c|}{ "dependent variable: dummy for adoption of new technologies } \\
\hline & $(1)$ & $(2)$ & $(3)$ & $(4)$ \\
\hline \multirow[t]{2}{*}{ Herfindahl index } & -0.065 & -0.092 & -0.218 & $-0.375^{*}$ \\
\hline & $(0.219)$ & $(0.235)$ & $(0.235)$ & $(0.223)$ \\
\hline \multirow{2}{*}{ firm size (log. number of employees) } & 0.033 & 0.017 & -0.013 & -0.027 \\
\hline & $(0.026)$ & $(0.028)$ & $(0.028)$ & $(0.029)$ \\
\hline \multirow[t]{2}{*}{ share of highly qualified employees } & 0.029 & -0.002 & 0.004 & 0.026 \\
\hline & $(0.104)$ & $(0.116)$ & $(0.115)$ & $(0.113)$ \\
\hline \multirow[t]{2}{*}{ firm age } & & 0.004 & 0.004 & $0.005^{* *}$ \\
\hline & & $(0.003)$ & $(0.003)$ & $(0.002)$ \\
\hline \multirow[t]{2}{*}{ exporter yes/no } & & 0.006 & -0.021 & -0.021 \\
\hline & & $(0.064)$ & $(0.065)$ & $(0.061)$ \\
\hline \multirow[t]{2}{*}{ foreign competitors yes/no } & & 0.082 & 0.056 & 0.025 \\
\hline & & $(0.060)$ & $(0.063)$ & $(0.062)$ \\
\hline \multirow[t]{2}{*}{ change of customer requirements yes/no } & & & $0.250^{* * *}$ & $0.202^{* * *}$ \\
\hline & & & $(0.065)$ & $(0.065)$ \\
\hline \multirow[t]{2}{*}{ enhancement of teamwork yes/no } & & & $0.126^{* *}$ & 0.068 \\
\hline & & & $(0.058)$ & $(0.058)$ \\
\hline \multirow[t]{2}{*}{ product innovation yes/no } & & & & $0.335^{* * *}$ \\
\hline & & & & $(0.061)$ \\
\hline number of observations & 356 & 320 & 284 & 259 \\
\hline McFadden $R^{2}$ & 0.03 & 0.04 & 0.11 & 0.21 \\
\hline
\end{tabular}

Significance levels : $\quad *: 10 \% \quad * *: 5 \% \quad * * *: 1 \%$ heteroscedasticity-robust standard errors

if they work in a team with younger colleagues. However, the data do not provide details on the composition of the working teams. Furthermore, employees of this age are supposed to be more experienced and may profit from sharing their knowledge with colleagues when it comes to technology adoption.

The detailed interpretation of the interaction effect is based on Figure A.3 in the appendix.15 For each interaction effect two graphs are presented. The first graph plots two effects: the interaction effect for each observation and the marginal effect calculated by the conventional linear method against predicted probabilities. The second graph of each interaction effect plots the z-statistics for each observation against predicted probabilities.

Table 4.3: Interaction effects: enhancement of teamwork and age groups

\begin{tabular}{|c|c|c|c|}
\hline $\begin{array}{l}\text { Interaction } \\
\text { between enhanced teamwork and ... }\end{array}$ & $\begin{array}{l}\text { mean } \\
\text { int. effect }\end{array}$ & $\begin{array}{c}\text { mean } \\
\text { std. error }\end{array}$ & $\begin{array}{c}\text { mean } \\
\text { z-statistic }\end{array}$ \\
\hline ...proportion of employees younger than 30 years & -0.655 & 0.319 & -1.951 \\
\hline ...proportion of employees between 30 and 40 years & 0.095 & 0.350 & 0.272 \\
\hline ...p proportion of employees between 40 and 55 years & 0.731 & 0.320 & 2.290 \\
\hline ...pproportion of employees older than 55 years & -0.600 & 0.479 & -1.214 \\
\hline
\end{tabular}

\footnotetext{
${ }^{15}$ Only the significant effects are reported.
} 
As the upper left graph in Figure A.3 in the appendix shows, firms with a higher proportion of workers younger than 30 years, which have enhanced teamwork in the last three years are less likely to adopt new technologies than firms that have not enhanced teamwork. This effect is lower for firms whose probability to adopt new technologies or software is rather low or rather high in absolute terms and higher for firms whose probability to adopt new technologies or software is around 0.5. The effect, however, is only significant for the latter firms, as can be seen in the upper right graph in Figure A.3 in the appendix. The effect is only significant for those firms whose predicted probability lies between 0.3 and 0.9 . This means that firms which are very likely or very unlikely to adopt new technologies are not affected by the joint impact of the age groups and the enhancement of teamwork. Regarding the interaction between the enhancement of teamwork and the proportion of employees between 40 and 55 years, the interaction effect is reverse. Firms that have enhanced teamwork in the last three years and have a higher proportion of employees between 40 and 55 years are more likely to adopt new technologies compared to firms that have not enhance teamwork. This effect is higher for firms whose probability to adopt new or significantly improved technologies is about 0.5 (see lower left graph in Figure A.3 in the appendix). Nevertheless, only firms that have a predicted probability to adopt new technologies between 0.25 and 0.85 have statistically significant effects, as can be seen in the lower right graph in Figure A.3 in the appendix. In that case as well the firms that are very likely or unlikely to adopt new technologies are not affected by the joint impact of age and teamwork.

The empirical results on the interaction effects suggest that the age structure of firms has to be combined with appropriate workplace organizations in order to keep up with the technological development. The combination of workers younger than 30 years and enhanced teamwork as a tool of workplace organization is negatively related to the probability of adopting new technologies, whereas the combination of workers between 40 and 55 years and enhanced teamwork is positively related to that probability. At first sight this seems to contradict former empirical evidence from the manufacturing sector. It finds that workplace reorganization is negatively related to the proportion of older employees in firms (e.g. Beckmann 2005, Aubert, Caroli, and Roger 2006) and therefore suggests that older employees and innovative workplace practices are no suitable match. However, the results presented here are considering service sector firms instead of firms belonging to the manufacturing sector. The classification of the age groups differs. Beckmann (2005) or Aubert, Caroli, and Roger (2006) find the negative effect for workers being 50 years or older whereas here it is the group of employees between 40 and 55 years that is positively linked with teamwork. Furthermore, firms that are very likely or very unlikely to adopt new technologies are not affected by the joint impact of enhanced teamwork and workers being younger than 30 years or between 40 and 55 years respectively. And this is also the interesting point in this result. It suggests that only those firms that are not determined in adopting new technologies or in not adopting them from the beginning can increase their probability to adopt new technologies by taking the age structure and the appropriate workplace organization in terms of teamwork into account. As technology adoption is a key factor in staying competitive the results suggest that firms with a high share of employees being younger than 30 years should 
abstain from enhancing teamwork whereas firms with a high proportion of employees between 40 and 55 years should enhance teamwork.

Besides the age of the workforce the adoption of new or significantly improved technologies is simultaneously affected by some other factors. The analysis however reveals that not all of the variables controlled for are significant. It can be seen that changed customer requirements positively affect the probability of adopting new or significantly improved technologies. Firms that had to face changed market or customer requirements within the last three years are more likely to adopt new technologies (see e.g. the last two columns of Tables 4.1 and 4.2). This result seems plausible since the provision of knowledge-intensive services and ICT services comes along with a high degree of interaction with clients and customers respectively (Koch and Strotmann 2006). On the other hand, the firms analyzed in this study are mostly small and medium-sized firms. De Jong and Brouwer (1999) find in their literature review that the customer information and a close cooperation is one of the main sources for (product) innovation in SMEs. Since, especially in the service sector, a change in the operating process through new methods (in this case particular new information and communication technologies) may lead to improved services, the influence of customer requirements is indispensable.

The enhancement of teamwork in the last three years as a tool of workplace organization is positively related to the probability of adopting new technologies at the firm-level (see fourth column of Tables 4.1 and 4.2 . This is in line with empirical analyses that arrive at the conclusion that the workplace organization matters in the context of innovation probability. Webster (2004) or Zoghi, Mohr, and Meyer (2007) for example find that the extent of innovation, i.e. the probability of innovation, is higher in firms that have a stronger communication between management and workers or decentralized structures and information-sharing. The same conclusions are drawn by Gera and Gu (2004), who show that measures beyond information-sharing programs like human resource management practices, including self-directed work groups (teamwork) significantly enhance the probability of introducing process innovations. However, the effect of enhanced teamwork turns to be insignificant if the dummy variable presenting product innovation is considered. This suggests that in general innovative firms also tend to be innovative regarding their workplace organization.

The introduction of product innovations is positively related to the likelihood of adopting new technologies and software. Firms that offer new services are more likely to adopt new technologies (see last column of Tables 4.1 and 4.2). On the one hand, this can be explained by a generally higher willingness of the firm to innovate or renew the operating process itself. On the other hand, product innovations and process innovations in the services sector cannot be easily distinguished. A process innovation, as the adoption of new or significantly improved technologies, allows to improve the quantity or quality of a provided service by keeping the input constant, reducing the supply costs or accelerating the process (Hempell 2003). This change in the provided service, caused by a process innovation, can in turn be interpreted as product innovation. The data do not offer apropriate instruments to control for endogeneity or 
simultaneity problems arising in this context.

To a certain extent the firm age is also positively related to the probability of adopting new technologies. Firms that are older are more likely to adopt new or significantly improved technologies (see Table 4.1). One reason for this may be that newly founded firms start with the latest technology. Another reason could be that older firms have more capital and are therefore more likely to invest in new technologies.

\section{Conclusion}

Using a cross-sectional data set of 356 firms of the German ICT and knowledge-intensive service providers in the year 2005 this paper provides empirical evidence that the age of the workforce is negatively related to the probability of adopting new or significantly improved technologies in service sector firms. Firms with a higher proportion of younger employees are more likely to adopt new technologies than firms with an older workforce. Furthermore, the older the workforce the less likely firms are to adopt new technologies. Since the adoption of new technologies, especially ICT, can be regarded as an innovation in the sectors of ICT and knowledge-intensive services, the results are in line with previous literature that provides evidence for the impact of the age of the workforce on the probability of technological change and innovations in the manufacturing industries. The structure of the age of the workforce, means the distribution of the age, however, has no significant relation to the adoption of new technologies.

On the one hand, the use of innovative workplace practices may provide a better environment for the adoption of new technologies and the relationship between ICT and workplace organization is complementary. On the other hand, innovative workplace practices are negatively related to the employment of older workers. Therefore, this paper closes a reserach gap by analyzing the joint impact of enhanced teamwork and the share of employees belonging to four different age groups. The results exhibit contrary effects. Firms that have enhanced their teamwork and have a high proportion of workers younger than 30 years are less likely to adopt new technologies than firms that did not change their workplace organization. Firms that have enhanced teamwork and have a higher proportion of employees between 40 and 55 years are more likely to adopt new technologies compared to firms without workplace reorganization. This result, however, is only significant for some firms in the sample, depending on their predicted probability to adopt new technologies. This means that firms which are very likely or very unlikely to adopt new technologies are not affected by the joint impact of the age groups and the enhancement of teamwork. It seems that firms with a certain age structure of the workforce need appropriate workplace organization to keep up with the technological development. As technology adoption is a key factor in staying competitive the results suggest that firms from the ICT and knowledge-intensive service sectors with a high share of employees being younger than 30 years should abstain from enhancing teamwork whereas firms with a high proportion of employees between 40 and 55 years should enhance teamwork.

Finally, the analyses show that there are further factors affecting the adoption of new or signif- 
icantly improved technologies. The firm age, to a certain extent the enhancement of teamwork, the introduction of product innovation and the change of market and customer requirements are positively related to the probability of technology adoption in ICT and knowledge-intensive service sector firms. Especially the relationships between technology adoption and changed market or customer requirements as well as product innovation seem to be very robust. As the analyzed firms belong to the ICT and knowledge-intensive service sectors and are mainly small and medium-sized they depend to a great extent on the interaction with their clients and customers and a close cooperation with them. Thus, new or changed requirements will lead to new services, that is product innovation. Or it will lead to changed or improved services which might be reached by process innovation, in these sectors that is the adoption of new technologies. Further research on technology adoption in service sector firms and especially in the ICT and knowldege intensive service sectors should therefore focus on this relation. The impact, its extent and the different facets of product innovation as well as the customers and their interaction should be analyzed to learn more about the determinants of technology adoption. All the more as the skills of the employees and the external environment of the firm in terms of competition and exporting do not seem to matter. 


\section{References}

Ai, C., And E. C. Norton (2003): "Interaction Terms in Logit and Probit Models," Economics Letters, 80, 123-129.

Aubert, P., E. Caroli, and M. Roger (2006): "New Technologies, Organisation and Age: Firm-Level Evidence," The Economic Journal, 116(509), 73-93.

Autor, D. H., F. Levy, and R. J. Murnane (2003): "The skill content of recent technological change: An empirical exploration," Quarterly Journal of Economics, 118(4), 1279-1333.

Beckmann, M. (2001): "Die Auswirkungen des betrieblichen Personalabbaus auf die Altersstruktur der Belegschaften in westdeutschen Unternehmen," in Entlohnung, Arbeitsorganisation und personalpolitische Regulierung, ed. by U. Backes-Gellner, M. Kräkel, D. Sadowski, and J. Mure, pp. 217-242. Rainer Hampp Verlag, München and Mering.

(2005): "Age-Biased Technological and Organizational Change: Firm-Level Evidence for West Germany," GEABA Discussion Paper No. 05-13.

Behaghel, L., and N. Greenan (2007): "Training and Age-Biased Technical Change," LEA Working Paper 0705.

BertscheK, I. (2004): "Führt IT-Nutzung zu altersfeindlicher Reorganisation von Arbeit? Eine Untersuchung auf Grundlage der IKT-Umfrage des ZEW," in Herausforderungen an den Wirtschaftsstandort Deutschland, ed. by B. Fitzenberger, W. Smolny, and P. Winker, vol. 72 of ZEW Wirtschaftsanalysen, pp. 249-263. Nomos, Baden-Baden.

BertscheK, I., And U. Kaiser (2004): "Productivity effects of organizational change: microeconometric evidence," Management Science, 50(3), 394-404.

Boockmann, B., And T. Zwick (2004): "Betriebliche Determinanten der Beschäftigung älterer Arbeitnehmer," Zeitschrift für ArbeitsmarktForschung, 37(1), 53-63.

Borghans, L., and B. ter Weel (2002): "Do Older Workers Have More Trouble Using a Computer than Younger Workers?," Research in Labor Economics, 21, 139-173.

Bresnahan, T. F., E. Brynjolfsson, and L. M. Hitt (2002): "Information technology, workplace organization, and the demand for skilled labor: firm-level evidence," The Quarterly Journal of Economics, 117(1), 339-376.

Börsch-Supan, A., I. Düzgün, And M. Weiss (2006): "Sinkende Produktivität alternder Belegschaften? Zum Stand der Forschung," in Länger leben, arbeiten und sich engagieren. Chancen wertschaffender Beschäftigung bis ins Alter, ed. by J. U. Prager, and A. Schleiter, pp. 85-102, Gürtersloh. Bertelsmann Stiftung.

Brynjolfsson, E., And L. M. Hitt (2000): "Beyond computation: information technology, organizational transformation and business performance," Journal of Economic Perspectives, $14(4), 23-48$. 
Card, D., and J. E. DiNardo (2002): "Skill-Biased Technological Change and Rising Wage Inequality: Some Problems and Puzzles," Journal of Labor Economics, 20(4), 733-783.

Chennells, L., and J. van Reenen (2002): "Technical change and the structure of employment and wages: A survey of the microeconometric evidence," in Productivity, Inequality and the Digital Economy, ed. by N. Greenan, Y. L'Horty, and J. Mairesse, pp. 175-223, Cambridge. MIT Press.

DE Jong, J. P. J., And E. Brouwer (1999): "Determinants of the Innovative Ability of SMEs," EIM Strategic Study B199902.

de Jong, J. P. J., A. Bruins, W. Dolfsma, and J. MeijaArd (2003): "Innovation in Service Firms explored: What, How and Why?," EIM Strategic Study B200205.

De Koning, J., And A. Gelderblom (2006): "ICT and Older Workers: No Unwrinkled Relationship," International Journal of Manpower, 27(5), 467-490.

Eurostat (2007): "Labour Force Survey main indicators (adjusted series-annual averages)," .

FALK, M. (2002): "Diffusion der Informations- und Kommunikationstechnologien und die Qualifikationsstruktur der Arbeitskräfte," Mitteilungen aus der Arbeitsmarkt- und Berufsforschung, $35(3), 397-410$.

Friedberg, L. (2003): "The Impact of Technological Change on Older Workers: Evidence from Data on Computer Use," Industrial and Labor Relations Review, 56(3), 511-529.

Gera, S., And W. Gu (2004): "The Effect of Organizational Innovation and Information Technology on Firm Performance," International Productivity Monitor, 9(Fall), 37-51, unabridged version.

Grund, C., and N. Westergard-Nielsen (2008): "Age Structure of the Workforce and Firm Performance," International Journal of Manpower, forthcoming.

Hempell, T. (2003): "Innovationen im Dienstleistungssektor," in Innovationsforschung heute, ed. by N. Janz, and G. Licht, vol. 63 of ZEW Wirtschaftsanalysen. Nomos, Baden-Baden.

Hitt, L. M., And E. Brynjolfssson (1997): "Information Technology and Internal Firm Organization: An Exploratory Analysis," Journal of Management Information Systems, 14, 81-101.

Kilduff, M., R. Angelmar, and A. Mehra (2000): "Top Management-Team Diversity and Firm Performance: Examining the Role of Cognitions," Organization Science, 11(1), 21-34.

Koch, A., and H. Strotmann (2006): "Determinants of Innovative Activity in Newly Founded Knowledge Intensive Business Service Firms," in Entrepreneurship in the Region, ed. by M. Fritsch, and J. Schmude, vol. 14 of International Studies in Entrepreneurship. Springer-Verlag.

Lazear, E. P. (1998): Personel Economics for Managers. John Wiley and Sons, New York. 
MacDonald, G., and M. S. Weisbach (2004): "The Economics of Has-beens," Journal of Political Economy, 112(1 pt. 2), 289-310.

Milgrom, P., And J. Roberts (1990): "The Economics of Modern Manufacturing: Technology, Strategy, and Organization," American Economic Review, 80, 511-528.

Morris, M. G., and V. Venkatesh (2000): "Age Differences in Technology Adoption Decisions: Implications for a Changing Work Force," Personnel Psychology, 53(2), 375-.

Mueller, E., And A. Spitz-Oener (2006): "Managerial Ownership and Company Performance in German Small and Medium-Sized Private Enterprises," German Economic Review, $7(2), 233-247$.

Nishimura, K. G., K. Minetaki, M. Shirai, and F. Kurokawa (2004): "Effects of Information Technology and Ageing Work Force on Labor Demand and Technological Progress in Japanese Industries: 1980-1998," in The Economics of an Ageing Population: Macroeconomic Issues, ed. by P. Onofri. Kluwer Publishing, Boston.

OECD, Eurostat (2005): Oslo Manual - Guidelines for Collecting and Interpreting Innovation Data. OECD, Paris, 3 edn.

Pelled, L. H., K. M. Eisenhardt, and K. R. Xin (1999): "Exploring the Black Box: An Analysis of Work Group Diversity, Conflict, and Performance," Administrative Science Quarterly, 44(1), 1-28.

Rouvinen, P. (2002): "Characteristics of Product and Process Innovators: Some Evidence from the Finnish Innovation Survey," Applied Economics Letters, 9(9), 575-580.

Schleife, K. (2006): "Computer Use and the Employment Status of Older Workers," LABOUR: Review of Labour Economics and Industrial Relations, 20(2), 325-348.

SchneIDER, L. (2007): "Alterung und technologisches Innovationspotential - Eine LinkedEmployer-Employee-Analyse," IWH-Discussion Papers, Januar 2007 Nr. 2.

Simons, T., L. H. Pelled, and K. A. Smith (1999): "Making Use of Differences: Diversity, Debate, and Decision Comprehensiveness in Top Management Teams," The Academy of Management Journal, 42(6), 662-673.

Spitz-Oener, A. (2006): "Technical Change, Job Tasks, and Rising Educational Demands: Looking outside the Wage Structure," Journal of Labor Economics, 24(2), 235-270.

Statistisches Bundesamt (2006): Volkswirtschaftliche Gesamtrechnungen - Inlandsproduktsberechnung, Lange Reihen ab 1970, Fachserie 18 Reihe 1.5. Statistisches Bundesamt, Nürnberg.

Tijdens, K., And B. SteiJn (2005): "The Determinants of ICT Competencies among Employees," New Technology, Work and Employment, 20(1), 60-73.

Walter, H. (1995): Das Alter leben! Wissenschaftliche Buchgesellschaft, Darmstadt. 
Webster, E. (2004): "Firms' Decisions to Innovate and Innovation Routines," Economics of Innovation and New Technology, 13(8), 733-745.

Weinberg, B. A. (2004): "Experience and Technology Adoption," IZA Discussion Paper No. 1051.

Zoghi, C., R. D. Mohr, and P. B. Meyer (2007): "Workplace Organization and Innovation," BLS working paper 405. 


\section{A Appendix}

The ZEW quarterly business survey among service providers of the information society includes the following industries (codes of the German Classification of Economic Activities, Edition 2003 in parentheses): software and IT services (71.33.0, 72.10.0-72.60.2), ICT-specialized trade (51.43.1, 51.43.3-3.4, 51.84.0, 52.45.2, 52.49.5-9.6), telecommunication services (64.30.1-0.4), tax consultancy and accounting (74.12.1-2.5), management consultancy (74.11.1-1.5, 74.13.13.2, 74.14.1-4.2), architecture (74.20.1-0.5), technical consultancy and planning (74.20.5-0.9), research and development (73.10.1-73.20.2) and advertising (74.40.1-0.2). Table A.1 shows, how the industries are distributed in the sample.

Table A.1: Distribution of industries in the sample

\begin{tabular}{l|c}
\hline \hline Industry & Percentage \\
\hline software and IT services & 9.55 \\
ICT-specialized trade & 17.13 \\
telecommunication services & 3.93 \\
tax consultancy and accounting & 17.13 \\
management consultancy & 8.43 \\
architecture & 13.76 \\
technical consultancy and planning & 11.80 \\
research and development & 12.08 \\
advertising & 6.18 \\
\hline sum & 100 \\
\hline \hline
\end{tabular}

Source: ZEW, own calculations

Table A.2: Summary statistics

\begin{tabular}{l|c|c}
\hline \hline Variable & $\begin{array}{c}\text { Number } \\
\text { of observations }\end{array}$ & Mean \\
\hline process innovation & 356 & 0.5112 \\
proportion of employees younger than 30 years & 356 & 0.2216 \\
proportion of employees between 30 and 40 years & 356 & 0.3263 \\
proportion of employees between 40 and 55 years & 356 & 0.3423 \\
proportion of employees older than 55 years & 356 & 0.1098 \\
Herfindahl index & 356 & 0.4128 \\
proportion of highly qualified employees & 356 & 0.3785 \\
enhancement of teamwork & 321 & 0.3988 \\
change of customer requirements & 318 & 0.6761 \\
firm size (number of employees) & 356 & 36.8 \\
firm age & 351 & 15.9 \\
foreign competitors & 330 & 0.5273 \\
product innovation & 319 & 0.5047 \\
exporter & 347 & 0.3516 \\
East Germany & 356 & 0.2556 \\
\hline \hline
\end{tabular}

Source: ZEW, own calculations 
Figure A.1: Proportion of firms that adopted new technologies by sectors

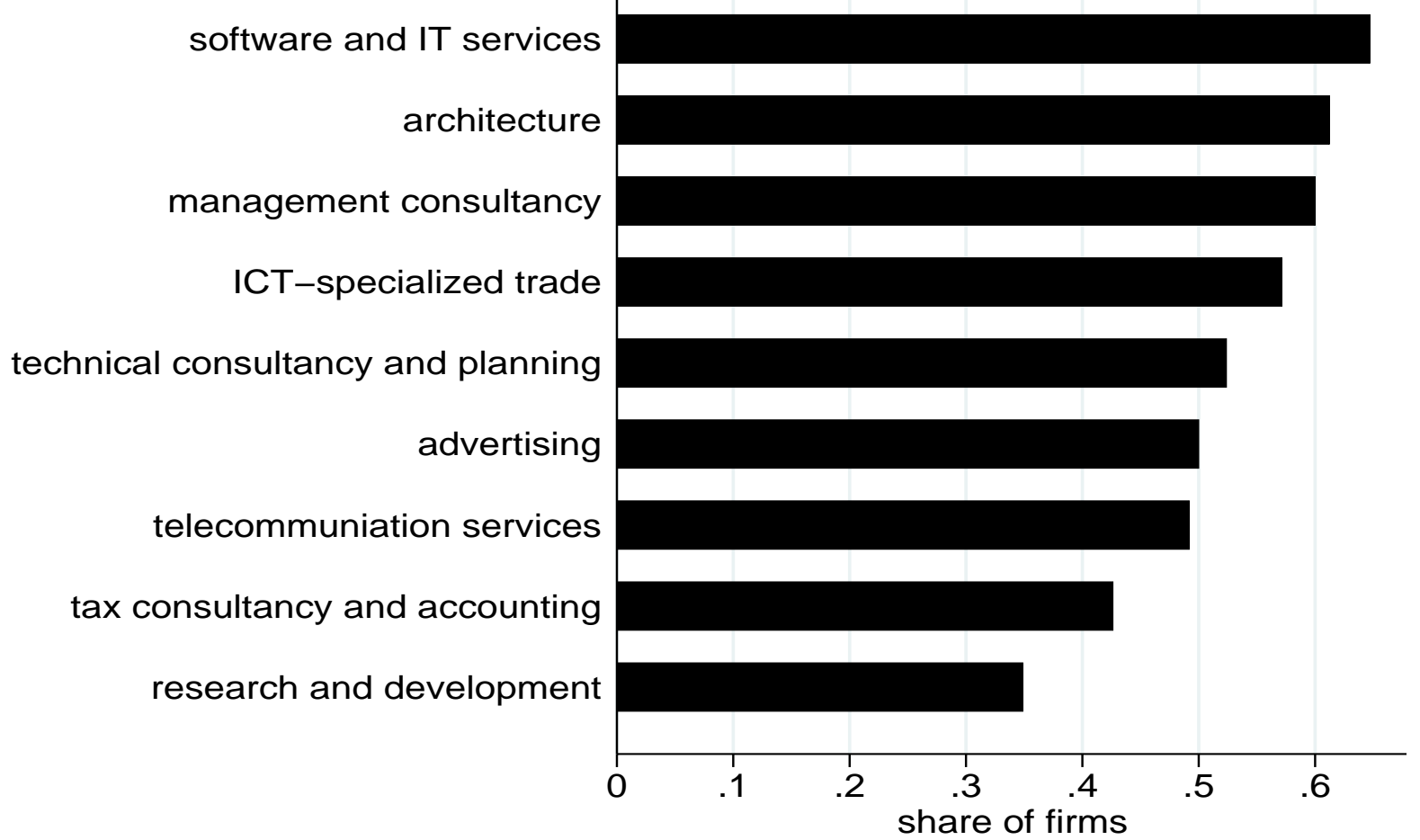

Source: ZEW, own calculations

Table A.3: Development of percentage shares of age groups

\begin{tabular}{l|lccccc}
\hline \hline Year & Variable & Obs & Mean & Std. Dev. & Min. & Max. \\
\hline \multirow{5}{*}{2002} & share of empl. below 30 years & 391 & 0.240 & 0.201 & 0 & 1 \\
& share of empl. between 30 and 40 years & 391 & 0.333 & 0.197 & 0 & 1 \\
& share of empl. between 40 and 55 years & 391 & 0.327 & 0.225 & 0 & 1 \\
& share of empl. above 55 years & 391 & 0.100 & 0.147 & 0 & 1 \\
\hline \multirow{5}{*}{2003} & share of empl. below 30 years & 437 & 0.224 & 0.187 & 0 & 1 \\
& share of empl. between 30 and 40 years & 437 & 0.322 & 0.204 & 0 & 1 \\
& share of empl. between 40 and 55 years & 437 & 0.354 & 0.248 & 0 & 1 \\
& share of empl. above 55 years & 437 & 0.100 & 0.151 & 0 & 1 \\
\hline \multirow{5}{*}{2004} & share of empl. below 30 years & 406 & 0.243 & 0.213 & 0 & 1 \\
& share of empl. between 30 and 40 years & 406 & 0.328 & 0.199 & 0 & 1 \\
& share of empl. between 40 and 55 years & 406 & 0.329 & 0.225 & 0 & 1 \\
& share of empl. above 55 years & 406 & 0.101 & 0.136 & 0 & 0.75 \\
\hline \multirow{5}{*}{2005} & share of empl. below 30 years & 362 & 0.216 & 0.192 & 0 & 1 \\
& share of empl. between 30 and 40 years & 362 & 0.317 & 0.195 & 0 & 1 \\
& share of empl. between 40 and 55 years & 362 & 0.355 & 0.224 & 0 & 1 \\
& share of empl. above 55 years & 362 & 0.112 & 0.145 & 0 & 1 \\
\hline \hline
\end{tabular}

Source: ZEW business survey among the "service providers of the information society" 2002, 2003, 2004, 2005 (in each case 3rd quarter) 
Figure A.2: Kernel density estimation
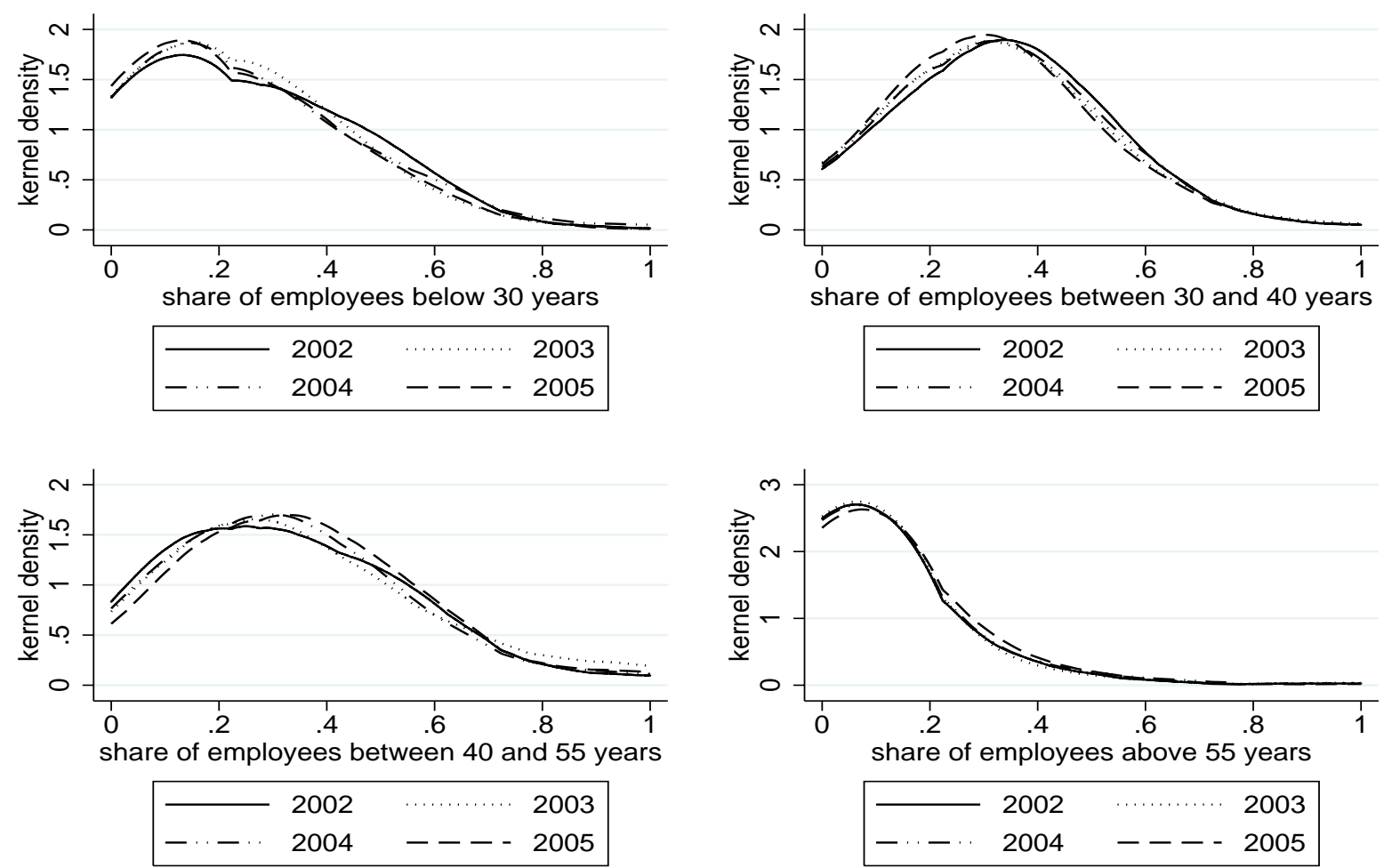

Source: ZEW business survey among the "service providers of the information society" 2002, 2003, 2004, 2005 (in each case 3rd quarter); in each case bandwith=0.1

Figure A.3: Interaction effects: enhancement of teamwork

Interaction Effects after Probit

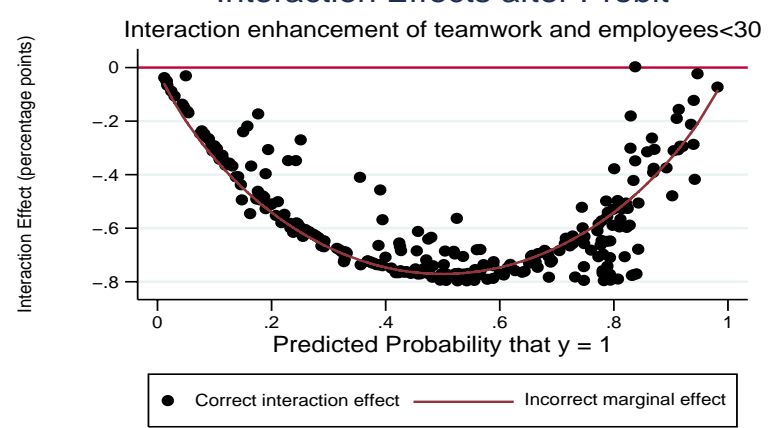

Interaction Effects after Probit

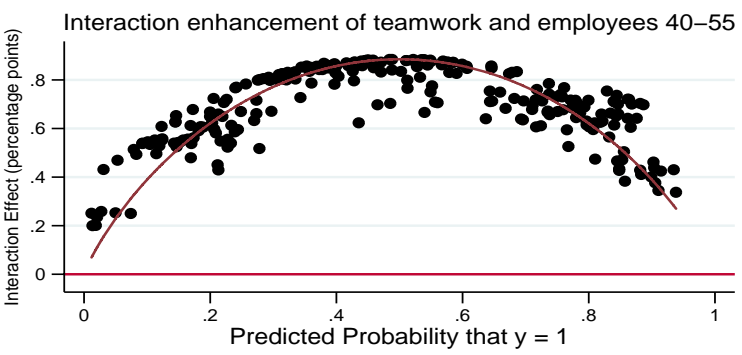

- Correct interaction effect Incorrect marginal effect

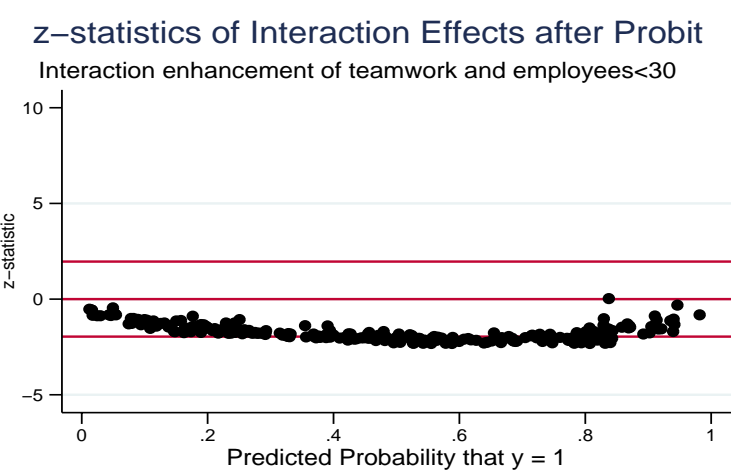

Z-statistics of Interaction Effects after Probit Interaction enhancement of teamwork and employees 40-55

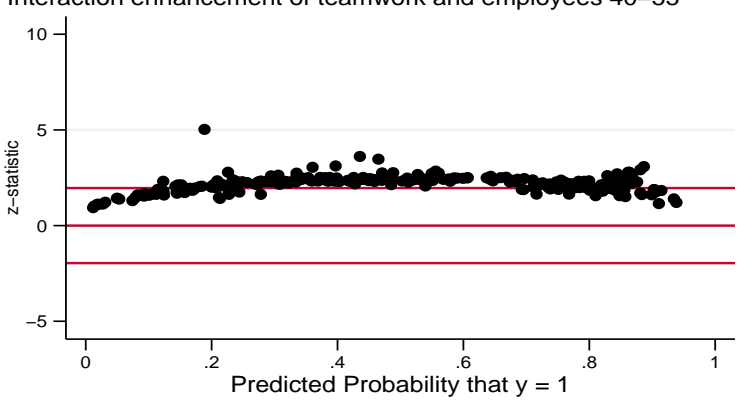

Source: Own calculations based on estimation of specification (5), 259 observations 
Table A.4: Coefficients of Probit Estimations: proportions of age groups

\begin{tabular}{|c|c|c|c|c|}
\hline \multicolumn{5}{|c|}{ dependent variable: dummy for adoption of new technologies } \\
\hline \multirow{3}{*}{$\begin{array}{l}\text { proportion of employees younger than } 30 \text { years } \\
\text { proportion of employees between } 30 \text { and } 40 \text { years }\end{array}$} & \multicolumn{4}{|c|}{ reference category } \\
\hline & $-0.912^{*}$ & $-0.931^{*}$ & $-1.003^{*}$ & $-1.063^{*}$ \\
\hline & $(0.468)$ & $(0.491)$ & $(0.569)$ & $(0.617)$ \\
\hline \multirow[t]{2}{*}{ proportion of employees between 40 and 55 years } & $-0.991^{* *}$ & $-1.100^{* *}$ & $-1.132^{* *}$ & $-1.324^{* *}$ \\
\hline & $(0.426)$ & $(0.445)$ & $(0.505)$ & $(0.520)$ \\
\hline \multirow[t]{2}{*}{ proportion of employees older than 55 years } & $-1.751^{* * *}$ & $-1.918^{* * *}$ & $-2.134^{* * *}$ & $-2.146^{* * *}$ \\
\hline & $(0.628)$ & $(0.656)$ & $(0.744)$ & $(0.810)$ \\
\hline \multirow[t]{2}{*}{ firm size (log. number of employees) } & 0.044 & 0.023 & -0.033 & -0.065 \\
\hline & $(0.064)$ & $(0.071)$ & $(0.078)$ & $(0.088)$ \\
\hline \multirow[t]{2}{*}{ proportion of highly qualified employees } & 0.171 & 0.132 & 0.127 & 0.138 \\
\hline & $(0.275)$ & $(0.308)$ & $(0.339)$ & $(0.376)$ \\
\hline \multirow{2}{*}{ firm age } & & -0.0005 & -0.001 & 0.007 \\
\hline & & $(0.005)$ & $(0.005)$ & $(0.007)$ \\
\hline \multirow{2}{*}{ exporter yes/no } & & -0.008 & -0.120 & -0.119 \\
\hline & & $(0.173)$ & $(0.189)$ & $(0.205)$ \\
\hline \multirow[t]{2}{*}{ foreign competitors yes/no } & & 0.195 & 0.134 & 0.110 \\
\hline & & $(0.160)$ & $(0.181)$ & $(0.203)$ \\
\hline \multirow[t]{2}{*}{ change of customer requirements yes/no } & & & $0.682^{* * *}$ & $0.645^{* * *}$ \\
\hline & & & $(0.180)$ & $(0.201)$ \\
\hline \multirow[t]{2}{*}{ enhancement of teamwork yes/no } & & & $0.381^{* *}$ & 0.234 \\
\hline & & & $(0.172)$ & $(0.189)$ \\
\hline \multirow{2}{*}{ product innovation yes/no } & & & & $0.933^{* * *}$ \\
\hline & & & & $(0.190)$ \\
\hline number of observations & 356 & 322 & 286 & 260 \\
\hline McFadden $R^{2}$ & 0.05 & 0.06 & 0.13 & 0.22 \\
\hline
\end{tabular}

Significance levels : $\quad *: 10 \% \quad * *: 5 \% \quad * * *: 1 \%$ heteroscedasticity-robust standard errors 
Table A.5: Coefficients of Probit Estimations: proportion of employees younger than 30 years

\begin{tabular}{|c|c|c|c|c|c|}
\hline \multicolumn{6}{|c|}{ dependent variable: dummy for adoption of new technologies } \\
\hline & $(1)$ & $(2)$ & $(3)$ & (4) & $(5)$ \\
\hline \multirow[t]{2}{*}{ proportion of employees younger than 30 years } & $1.123^{* * *}$ & $1.408^{* * *}$ & $1.437^{* * *}$ & $1.657^{* * *}$ & $2.656^{* * *}$ \\
\hline & (0.383) & $(0.400)$ & $(0.469)$ & $(0.497)$ & $(0.662)$ \\
\hline \multirow[t]{2}{*}{ firm size (log. number of employees) } & 0.057 & 0.005 & -0.051 & -0.073 & -0.091 \\
\hline & $(0.063)$ & $(0.070)$ & $(0.078)$ & $(0.087)$ & $(0.087)$ \\
\hline \multirow[t]{2}{*}{ proportion of highly qualified employees } & 0.197 & 0.180 & 0.180 & 0.232 & 0.257 \\
\hline & $(0.272)$ & $(0.308)$ & $(0.338)$ & $(0.382)$ & $(0.388)$ \\
\hline \multirow[t]{2}{*}{ firm age } & & 0.013 & $0.014^{*}$ & $0.019^{* *}$ & $0.021^{* *}$ \\
\hline & & $(0.008)$ & $(0.008)$ & $(0.009)$ & $(0.009)$ \\
\hline \multirow[t]{2}{*}{ exporter yes/no } & & -0.007 & -0.091 & -0.113 & -0.153 \\
\hline & & $(0.172)$ & $(0.188)$ & $(0.202)$ & $(0.204)$ \\
\hline \multirow[t]{2}{*}{ foreign competitors yes/no } & & 0.192 & 0.132 & 0.071 & 0.066 \\
\hline & & $(0.159)$ & $(0.179)$ & $(0.200)$ & $(0.200)$ \\
\hline \multirow[t]{2}{*}{ change of customer requirements yes/no } & & & $0.705^{* * *}$ & $0.659^{* * *}$ & $0.763^{* * *}$ \\
\hline & & & $(0.182)$ & $(0.201)$ & $(0.210)$ \\
\hline \multirow[t]{2}{*}{ enhancement of teamwork yes/no } & & & $0.323^{*}$ & 0.189 & $0.721^{* *}$ \\
\hline & & & $(0.171)$ & $(0.187)$ & $(0.304)$ \\
\hline \multirow{4}{*}{$\begin{array}{l}\text { interaction } \\
\text { teamwork*proportion of employees younger than } 30 \\
\text { product innovation yes/no }\end{array}$} & & & & & $-2.283^{* *}$ \\
\hline & & & & & $(0.951)$ \\
\hline & & & & $0.957^{* * *}$ & $0.938^{* * *}$ \\
\hline & & & & $(0.190)$ & $(0.189)$ \\
\hline number of observations & 356 & 320 & 284 & 259 & 259 \\
\hline McFadden $R^{2}$ & 0.05 & 0.07 & 0.14 & 0.23 & 0.24 \\
\hline
\end{tabular}

Significance levels : $\quad *: 10 \% \quad * *: 5 \% \quad * * *: 1 \%$ heteroscedasticity-robust standard errors 
Table A.6: Coefficients of Probit Estimations: proportion of employees between 30 and 40 years

\begin{tabular}{|c|c|c|c|c|c|}
\hline \multicolumn{6}{|c|}{ dependent variable: dummy for adoption of new technologies } \\
\hline & $(1)$ & $(2)$ & $(3)$ & $(4)$ & $(5)$ \\
\hline \multirow[t]{2}{*}{ proportion of employees between 30 and 40 years } & 0.020 & 0.162 & 0.094 & 0.066 & -0.034 \\
\hline & $(0.365)$ & $(0.398)$ & $(0.447)$ & $(0.493)$ & $(0.566)$ \\
\hline \multirow[t]{2}{*}{ firm size (log. number of employees) } & 0.095 & 0.053 & -0.010 & -0.028 & -0.029 \\
\hline & $(0.062)$ & $(0.068)$ & $(0.075)$ & $(0.085)$ & $(0.085)$ \\
\hline \multirow[t]{2}{*}{ proportion of highly qualified employees } & 0.061 & -0.043 & -0.040 & -0.016 & -0.028 \\
\hline & $(0.271)$ & $(0.306)$ & $(0.333)$ & $(0.367)$ & $(0.364)$ \\
\hline \multirow[t]{2}{*}{ firm age } & & 0.010 & 0.011 & $0.016^{* *}$ & $0.017^{* *}$ \\
\hline & & $(0.008)$ & $(0.008)$ & $(0.008)$ & $(0.008)$ \\
\hline \multirow[t]{2}{*}{ exporter yes/no } & & 0.018 & -0.070 & -0.084 & -0.084 \\
\hline & & $(0.169)$ & $(0.186)$ & $(0.199)$ & $(0.199)$ \\
\hline \multirow{2}{*}{ foreign competitors yes/no } & & 0.216 & 0.171 & 0.106 & 0.106 \\
\hline & & $(0.158)$ & $(0.177)$ & $(0.195)$ & $(0.195)$ \\
\hline \multirow[t]{2}{*}{ change of customer requirements yes/no } & & & $0.682^{* * *}$ & $0.606^{* * *}$ & $0.609^{* * *}$ \\
\hline & & & $(0.179)$ & $(0.19)$ & $(0.199)$ \\
\hline \multirow[t]{2}{*}{ enhancement of teamwork yes/no } & & & $0.366^{* *}$ & 0.245 & 0.148 \\
\hline & & & $(0.170)$ & $(0.187)$ & $(0.393)$ \\
\hline \multirow{4}{*}{$\begin{array}{l}\text { interaction } \\
\text { teamwork* proportion of employees between } 30 \text { and } 40 \\
\text { product innovation yes/no }\end{array}$} & & & & & 0.302 \\
\hline & & & & & $(1.104)$ \\
\hline & & & & $0.930^{* * *}$ & $0.931^{* * *}$ \\
\hline & & & & $(0.187)$ & $(0.187)$ \\
\hline number of observations & 356 & 320 & 284 & 259 & 259 \\
\hline McFadden $R^{2}$ & 0.03 & 0.04 & 0.11 & 0.20 & 0.20 \\
\hline
\end{tabular}

Significance levels : $\quad *: 10 \% \quad * *: 5 \% \quad * * *: 1 \%$ heteroscedasticity-robust standard errors 
Table A.7: Coefficients of Probit Estimations: proportion of employees between 40 and 55 years

\begin{tabular}{|c|c|c|c|c|c|}
\hline \multicolumn{6}{|c|}{ dependent variable: dummy for adoption of new technologies } \\
\hline & $(1)$ & $(2)$ & $(3)$ & $(4)$ & $(5)$ \\
\hline \multirow[t]{2}{*}{ proportion of employees between 40 and 55 years } & -0.454 & $-0.700^{*}$ & $-0.665^{*}$ & $-0.815^{*}$ & $-1.537^{* * *}$ \\
\hline & $(0.342)$ & $(0.371)$ & $(0.405)$ & $(0.421)$ & $(0.514)$ \\
\hline \multirow[t]{2}{*}{ firm size (log. number of employees) } & 0.082 & 0.036 & -0.030 & -0.050 & -0.059 \\
\hline & $(0.063)$ & $(0.069)$ & $(0.077)$ & $(0.086)$ & $(0.087)$ \\
\hline \multirow[t]{2}{*}{ proportion of highly qualified employees } & 0.055 & -0.016 & -0.016 & 0.013 & 0.058 \\
\hline & $(0.269)$ & $(0.305)$ & $(0.334)$ & $(0.375)$ & $(0.371)$ \\
\hline \multirow[t]{2}{*}{ firm age } & & 0.012 & 0.012 & $0.018^{* *}$ & $0.019^{* *}$ \\
\hline & & $(0.008)$ & $(0.008)$ & $(0.008)$ & $(0.008)$ \\
\hline \multirow[t]{2}{*}{ exporter yes/no } & & 0.037 & -0.062 & -0.082 & -0.121 \\
\hline & & $(0.170)$ & $(0.186)$ & $(0.200)$ & $(0.202)$ \\
\hline \multirow[t]{2}{*}{ foreign competitors yes/no } & & 0.182 & 0.137 & 0.069 & 0.066 \\
\hline & & $(0.159)$ & $(0.180)$ & $(0.199)$ & $(0.202)$ \\
\hline \multirow[t]{2}{*}{ change of customer requirements yes/no } & & & $0.689^{* * *}$ & $0.613^{* * *}$ & $0.695^{* * *}$ \\
\hline & & & $(0.180)$ & $(0.199)$ & $(0.205)$ \\
\hline \multirow[t]{2}{*}{ enhancement of teamwork yes/no } & & & $0.358^{* *}$ & 0.237 & -0.550 \\
\hline & & & $(0.169)$ & $(0.184)$ & $(0.355)$ \\
\hline \multirow{4}{*}{$\begin{array}{l}\text { interaction } \\
\text { teamwork* proportion of employees between } 40 \text { and } 55 \\
\text { product innovation yes/no }\end{array}$} & & & & & $2.390^{* *}$ \\
\hline & & & & & $(0.925)$ \\
\hline & & & & $0.947^{* * *}$ & $0.940^{* * *}$ \\
\hline & & & & $(0.188)$ & $(0.189)$ \\
\hline number & 356 & 320 & 284 & 259 & 259 \\
\hline McFadden $R^{2}$ & 0.03 & 0.05 & 0.12 & 0.21 & 0.23 \\
\hline
\end{tabular}

Significance levels : $\quad *: 10 \% \quad * *: 5 \% \quad * * *: 1 \%$ heteroscedasticity-robust standard errors 
Table A.8: Coefficients of Probit Estimations: proportion of employees older than 55 years

\begin{tabular}{|c|c|c|c|c|c|}
\hline \multicolumn{6}{|c|}{ dependent variable: dummy for adoption of new technologies } \\
\hline & $(1)$ & $(2)$ & $(3)$ & $(4)$ & $(5)$ \\
\hline proportion of employees older than 55 years & $\begin{array}{c}-1.203^{* *} \\
(0.571)\end{array}$ & $\begin{array}{c}-1.535^{* *} \\
(0.609)\end{array}$ & $\begin{array}{c}-1.686^{* *} \\
(0.687)\end{array}$ & $\begin{array}{c}-1.597^{* *} \\
(0.771)\end{array}$ & $\begin{array}{l}-0.815 \\
(0.910)\end{array}$ \\
\hline firm size (log. number of employees) & $\begin{array}{c}0.070 \\
(0.063)\end{array}$ & $\begin{array}{c}0.024 \\
(0.070)\end{array}$ & $\begin{array}{l}-0.036 \\
(0.076)\end{array}$ & $\begin{array}{c}-0.048 \\
(0.086)\end{array}$ & $\begin{array}{l}-0.050 \\
(0.085)\end{array}$ \\
\hline proportion of highly qualified employees & $\begin{array}{c}0.065 \\
(0.269)\end{array}$ & $\begin{array}{c}-0.029 \\
(0.304)\end{array}$ & $\begin{array}{l}-0.056 \\
(0.333)\end{array}$ & $\begin{array}{c}-0.051 \\
(0.370)\end{array}$ & $\begin{array}{l}-0.086 \\
(0.371)\end{array}$ \\
\hline firm age & & $\begin{array}{c}0.012 \\
(0.008)\end{array}$ & $\begin{array}{c}0.013 \\
(0.008)\end{array}$ & $\begin{array}{c}0.018^{* *} \\
(0.008)\end{array}$ & $\begin{array}{l}0.019^{* *} \\
(0.009)\end{array}$ \\
\hline exporter yes/no & & $\begin{array}{l}-0.025 \\
(0.170)\end{array}$ & $\begin{array}{l}-0.120 \\
(0.188)\end{array}$ & $\begin{array}{l}-0.130 \\
(0.201)\end{array}$ & $\begin{array}{l}-0.128 \\
(0.203)\end{array}$ \\
\hline foreign competitors yes/no & & $\begin{array}{c}0.229 \\
(0.158)\end{array}$ & $\begin{array}{c}0.176 \\
(0.177)\end{array}$ & $\begin{array}{c}0.118 \\
(0.195)\end{array}$ & $\begin{array}{c}0.108 \\
(0.195)\end{array}$ \\
\hline change of customer requirements yes/no & & & $\begin{array}{c}0.672^{* * *} \\
(0.181)\end{array}$ & $\begin{array}{c}0.597^{* * *} \\
(0.201)\end{array}$ & $\begin{array}{c}0.598^{* * *} \\
(0.203)\end{array}$ \\
\hline enhancement of teamwork yes/no & & & $\begin{array}{l}0.396^{* *} \\
(0.168)\end{array}$ & $\begin{array}{c}0.269 \\
(0.182)\end{array}$ & $\begin{array}{l}0.469^{* *} \\
(0.229)\end{array}$ \\
\hline $\begin{array}{l}\text { interaction } \\
\text { teamwork*proportion of employees older than } 55\end{array}$ & & & & & $\begin{array}{l}-2.011 \\
(1.507)\end{array}$ \\
\hline product innovation yes/no & & & & $\begin{array}{c}0.915^{* * *} \\
(0.187)\end{array}$ & $\begin{array}{c}0.935^{* * *} \\
(0.189)\end{array}$ \\
\hline numb & 356 & 320 & 284 & 259 & 259 \\
\hline McFadden $R^{2}$ & 0.04 & 0.06 & 0.13 & 0.21 & 0.22 \\
\hline
\end{tabular}

Significance levels : $\quad *: 10 \% \quad * *: 5 \% \quad * * *: 1 \%$ heteroscedasticity-robust standard errors 
Table A.9: Coefficients of Probit Estimations: age concentration

\begin{tabular}{lcccc}
\hline \hline \multicolumn{4}{c}{ dependent variable: dummy for adoption of new } & technologies \\
\hline Herfindahl index & -0.170 & -0.240 & -0.622 & -1.214 \\
& $(0.569)$ & $(0.618)$ & $(0.675)$ & $(0.738)$ \\
firm size (log. number of employees) & 0.087 & 0.044 & -0.037 & -0.087 \\
& $(0.068)$ & $(0.073)$ & $(0.081)$ & $(0.094)$ \\
proportion of highly qualified employees & 0.074 & -0.004 & 0.012 & 0.083 \\
& $(0.269)$ & $(0.304)$ & $(0.330)$ & $(0.366)$ \\
firm age & & 0.010 & -0.011 & $0.016^{* *}$ \\
& & $(0.008)$ & $(0.008)$ & $(0.008)$ \\
exporter yes/no & & $(0.016$ & -0.062 & -0.070 \\
& & 0.214 & $(0.186)$ & $(0.200)$ \\
foreign competitors yes/no & & $(0.158)$ & $(0.159$ & 0.080 \\
& & & $0.690^{* * *}$ & $(0.199)$ \\
change of customer requirements yes/no.618** & & $(0.179)$ & $(0.200)$ \\
enhancement of teamwork yes/no & & & $0.353^{* *}$ & 0.215 \\
& & & $(0.168)$ & $(0.184)$ \\
product innovation yes/no & & & $0.970^{* * *}$ \\
& & & & $(0.189)$ \\
\hline number of observations & 356 & 320 & 284 & 259 \\
McFadden $R^{2}$ & 0.03 & 0.04 & 0.11 & 0.21 \\
\hline \hline
\end{tabular}

Significance levels : $\quad *: 10 \% \quad * *: 5 \% \quad * * *: 1 \%$ heteroscedasticity-robust standard errors 